\title{
JEWISH RESPONSIBILITY FOR THE CROSS IN LUKE-ACTS1
}

\author{
Jon A. Weatherly
}

Since the appearance of Franz Overbeck's commentary on Acts in 1870, scholars have struggled to define the role of Judaism in Luke-Acts. Following Overbeck's lead, much Lukan criticism has either asserted or assumed that Luke regards all Jews as sharing in responsibility for the crucifixion of Jesus and so standing under God's condemnation. Speech material in Acts ascribing responsibility for the cross to Jews is consequently understood as a Lukan creation, a facet of the wider anti-Jewish polemic which characterises the Lukan corpus. This thesis addresses both of these issues: responsibility for the cross in the wider treatment of Jews in Luke-Acts and the origin of material in Acts ascribing responsibility for the cross to Jews.

Close analysis of the relevant texts indicates that Luke in fact does not directly ascribe responsibility for the cross to all Jews but only to Jerusalem specifically. The Sanhedrin leaders, consistently associated with Jerusalem in Luke and Acts, are the focus of this indictment. In the speeches of Acts, however, the people of Jerusalem are likewise charged. The accusation against the people of Jerusalem is consistent with the actions of the crowd before Pilate in Luke's Gospel, but the specific identification of the crowd as Jerusalemite is found only in the speeches of Acts. Furthermore, Luke apportions responsibility for the cross to Gentiles as well. Thus, according to Luke not all Jews are responsible for Jesus' death, and not all those responsible are Jews.

Though Luke does not directly indict all Jews for the death of Jesus, it remains possible that by focusing on Jerusalem and the Sanhedrin Luke assigns responsibility to entities which represent the entire Jewish people. Any indication that Luke regards the Jewish nation as a whole as having rejected Jesus and the gospel or that he regards all Israel

${ }^{1}$ Jon A. Weatherly, Jewish Responsibility for the Cross in Luke-Acts (Unpublished PhD Thesis, Aberdeen University, 1991), supervisor: Dr. Max Turner. 
as standing under God's condemnation could well be related to some form of national responsibility for the crucifixion. Such ideas have indeed been attributed to Luke, but examination of the evidence suggests that his emphasis is otherwise. Generalised expressions ('the people', 'this generation', 'the Jews') are used by Luke to specify particular groups in context, not to condemn Jews generally. The notion that the narrative structure of Luke-Acts indicates a final Jewish rejection of the gospel and the end of the church's Jewish mission likewise does not bear scrutiny. Rather, Luke regards the Jews' response to Jesus and the gospel as a divided one. Such a response, in Luke's rendering, is consistent with Israel's history as indicated in the Scriptures. So for Luke the Jewish mission continues as Acts closes, meeting with the same paradoxically divided response as some Jews believe the gospel and others reject it. Therefore, in the absence of any consistent condemnation of the Jews as a whole in Luke-Acts, there is no ground for seeing Jerusalem's responsibility for the cross as an indictment of all Jews.

This conclusion reopens the question of the tradition history of material in the speeches of Acts ascribing responsibility to the cross. If Luke does not condemn all Israel for the cross, is this material indeed Luke's own creation? 1 Thessalonians 2:14-16 is examined in this regard and is found to give evidence of Paul's adaptation of an existing poetic tradition. It is therefore significant that this evidently primitive text ascribes responsibility for the cross to Jews who are specifically associated with Judea, a feature consistent with Luke's ascription of responsibility to Jerusalem.

Comparison to the other synoptics shows that in assigning responsibility for the cross in his Gospel, Luke depends on his sources. All the synoptics share an emphasis on Jerusalem and the Sanhedrin, and all implicate Pilate and a crowd of Jewish people as well. That crowd, however, is of uncertain identity in the synoptic material.

Though it has been widely assumed that Luke merely extended the synoptic tradition to create the accusation of the cross in the speeches of Acts, the synoptic material alone is insufficient to explain the material in Acts. In Acts the people of Jerusalem are specifically indicted, but in the synoptics the crowd which calls for Jesus' death is never specifically 
identified as Jerusalemite. Furthermore, Luke's emphasis on the divided response of Israel to Jesus is not advanced by the indictment of the people of Jerusalem. It is therefore most unlikely that he created the material ascribing responsibility to the people of Jerusalem in order to serve his narrative or theological agenda. The remaining alternative is that Luke incorporated traditional material in Acts which, though complementary to the synoptic passion narrative, was independent of it. This explanation is the only one which adequately accounts for all the relevant data.

So evidence of pre-Lukan traditions about responsibility for the cross can be found in Paul and the synoptics as well as in Acts. But did a Sitz im Leben exist in which such traditions would be transmitted? In Acts this material is found in two settings: as a response to persecution and in proclamation of the death and resurrection of Jesus. Use of such material in the setting of persecution is confirmed by the similar use in 1 Thessalonians 2:14-16, but a setting in the kerygma is more problematic. The so-called kerygmatic summary in 1 Corinthians 15:3ff. says nothing about responsibility for the cross; accordingly, the conclusion has been drawn that the primitive kerygma did not include such statements. However, a comparison to a range of Jewish, pagan and Christian literature about the persecution or execution of innocent victims indicates that statements about the responsibility for Jesus' death would have been an integral part of preaching about the cross. This literature shows a distinct tendency to specify the persecutor of an innocent victim, even though such identification is not the text's primary purpose. A 'moral constraint' appears to be at work in such texts: if the victim is innocent, the one who seeks to slay him must be guilty and so must be specified. Because the vindication of the crucified messiah was indeed an integral theme of the primitive Christian kerygma, then some identification of those responsible for his death would be integral as well.

The implications of this study are clear. One is that Luke's skill and care as a historian are confirmed. In his two volumes he has integrated independent, complementary traditions which have their origin near to the actual events. Another implication is that allegations of Luke's antisemitism can be dismissed. Ascription of responsibility for Jesus' death 
to some Jews without excluding the responsibility of Gentiles does not constitute hostility to Jews as such, and neither does emphasis on the division of Israel in response to the gospel. Hostility in Luke-Acts is confined to those who reject Jesus and the gospel, whether Jews or Gentiles. 